2010-01-01

\title{
In Vitro Mammalian Cytotoxicological Study of PAMAM Dendrimers -towards Quantitative Structure Activity Relationships
}

Sourav Prasanna Mukherjee

sourav.mukherjee@tudublin.ie

Maria Davoren

Technological University Dublin, Maria.davoren@tudublin.ie

Hugh Byrne

Technological University Dublin, hugh.byrne@tudublin.ie

Follow this and additional works at: https://arrow.tudublin.ie/nanolart

\section{Recommended Citation}

Mukherjee, S., Davoren M. \& Byrne, H. (2010) In Vitro Mammalian Cytotoxicological Study of PAMAM Dendrimers -Towards Quantitative Structure Activity Relationships. Toxicology in Vitro, Vol.24, Issue 1, Pages 169-177. doi:10.1016/j.tiv.2009.09.014

This Article is brought to you for free and open access by the NanoLab at ARROW@TU Dublin. It has been accepted for inclusion in Articles by an authorized administrator of ARROW@TU Dublin. For more information, please contact arrow.admin@tudublin.ie, aisling.coyne@tudublin.ie,gerard.connolly@tudublin.ie. Funder: INSPIRE programme, funded by the Irish Government's Programme for Research in Third Level Institutions, Cycle 4, National Development Plan 20072013, supported by the European Union Structural Fund. 
In vitro mammalian cytotoxicological study of PAMAM dendrimers -towards quantitative structure activity relationships

Sourav Prasanna Mukherjee ${ }^{a, b^{*}}$, Maria Davoren ${ }^{a, b}$, Hugh J. Byrne

${ }^{a}$ Radiation and Environmental Science Centre, Focas Research Institute, Dublin Institute of Technology, Kevin Street, Dublin 8, Ireland.

${ }^{b}$ Nanolab, Focas Research Institute, Dublin Institute of Technology, Kevin Street, Dublin 8, Ireland.

${ }^{*}$ Corresponding Author

Sourav Prasanna Mukherjee

RESC, Focas Research Institute,

Dublin Institute of Technology

Kevin Street, Dublin 8, Ireland.

E mail address: sourav.mukherjee@dit.ie

$\mathrm{Ph}:+35314027999$

Fax: +35314027901 


\section{Introduction}

Nanostructured materials show great potential in near-term medical applications. Highly sophisticated technologies are emerging to identify novel therapeutic strategies (e.g., diagnostics, targeted drug delivery, gene therapy etc.) and to improve treatments for life threatening diseases. In this respect, polymers have shown great potential in drug (Yiyun et al., 2005) and gene delivery (Storrie and Mooney, 2006), and neural prosthetics (George et al., 2005).

Dendritic polymer nano-particles such as Polyamidoamine (PAMAM) dendrimers (Figure 1) have a similar potential for biomedical applications. They are highly branched radial polymers that have specific and systematically variable size, shape and chemical structure. Their radial structure contains a 2-carbon ethylenediamine core and primary amino groups on the surface. Successive generations (referred to as G0-G10) have increasing diameter and double the surface functional amino groups than the preceding generation (www.dendritech.com/pamam.html). The systematically variable structural architecture and the large internal free volume make these dendrimers an attractive candidate for biomedical applications.

A folate functionalized gadolinium-loaded PAMAM dendrimer of generation 5 has been reported as a MRI contrast agent for tumor cells expressing high affinity folate receptors (Swanson et al. 2008). The use of a PAMAM dendrimer based MRI contrast agent which can detect renal injury prior to the elevation of creatinine levels has also been reported (Dear et al., 2006). PAMAM dendrimers of different generations have also been employed for enhancing the solubility of poorly water-soluble drugs, e.g., ketoprofen, whereby the drug solubility increases with the dendrimer concentration, $\mathrm{pH}$ and generation (Yiyun et al., 2005). It has also been reported that the in vitro release of ketoprofen from the drug-dendrimer complex is significantly slower compared to pure ketoprofen ( $\mathrm{Na}$ et al, 2006) and anti-nociceptive studies using the acetic acid-induced writhing model in mice showed a prolonged pharmacodynamic behaviour for the ketoprofen-PAMAM dendrimer complex ( $\mathrm{Na}$ et al, 2006). It has therefore been suggested that PAMAM dendrimers can be considered as a potential drug carrier of ketoprofen with a sustained release behavior under suitable conditions ( $\mathrm{Na}$ et al, 2006). PAMAM dendrimers have also been shown to be a potent transfection agent for DNA and 
oligonucleotides (Guillot-Nieckowski et al., 2007). It is reported that PAMAM dendrimers help in the delivery of siRNA, and protect it from enzymatic degradation. They also stimulate release of siRNA over an extended period of time for efficient gene silencing (Zhou et al., 2006). Starpharma (Melbourne, Australia) has produced a dendrimer based medicine VivaGel ${ }^{\circledR}$, a vaginal microbicidal gel, for the prevention of sexually transmitted infections (STIs) including genital herpes and HIV. It is based on the antiviral properties of SPL7013, a lysine based dendrimer with naphthalene disulphonic acid surface groups, and has been successfully tested in an FDA approved Phase-I clinical trial (http://www.starpharma.com/vivagel.asp).

While the potential commercial applications of such dendrimers have received considerable attention, little is known about their possible adverse effects on both humans and the environment. To date there has been a few studies (both in vitro and in vivo). investigating the mammalian toxicity of dendrimers. There is some conflicting evidence regarding their biological safety (Robert et al., 1996; Malik et al., 2000; Klajnert et al., 2004;). It has recently been reported that the PAMAM dendrimer of generation 4 exhibits toxicity to zebra fish embryos (Heiden et al., 2007). A recent multitrophic ecotoxicological study of three dendrimers (G4, G5 and G6), demonstrated significant toxicity, increasing with increasing dendrimer generation (Naha et al., 2009b). Another group has shown an increasing toxic response with increasing generation on Caco-2 cells, an immortalized line of heterogeneous human epithelial colorectal adenocarcinoma cells (Jevprasesphant et al, 2003). Both studies have shown that surface modification plays an important role in the observed toxic response with half generation PAMAM dendrimers (e.g., G2.5, G3.5) with terminal carboxylic functional groups being less toxic than full generation PAMAM dendrimers $(\mathrm{G} 2, \mathrm{G} 3, \mathrm{G} 4)$ with terminal amino functional groups. It is also reported that PAMAM dendrimers cause hole formation in the plasma membrane which may lead to membrane disruption (Leroueil et al., 2008; Hong et al., 2004).

This study reports on the in vitro toxicological assessment of full generation PAMAM dendrimers. For the study, the commercially available PAMAM generation 4, 5 and 6 (G4, G5, G6) were chosen for cytotoxicity evaluation. The diameters of these nano-size dendrimers increase with increasing generation and the number of their surface functional primary amino groups also doubles with each successive generation. As there is currently 
huge commercial interest for their use in various pharmaceutical products, the evaluation of mammalian toxicity for both occupational and consumer exposure is paramount. Therefore, two mammalian cell lines- a dermal cell line and a colon cell line were employed for cytotoxicity testing. Although the models probe basal rather than systemic toxicity, and indeed it is questionable whether in vitro models can be extrapolated to in vivo responses, the study examines the variability of the responses and potentially underlying mechanisms for different cell lines. For example, as oxidative stress is a potential toxic injury, a significant difference between the cell lines employed is the level of antioxidants. HaCaT cells have more than 150 times more glutathione (GSH) than SW480 cells (Snow et al., 2005, Nakagawa et al., 2002). Cytotoxicity parameters, including the metabolic, lysosomal and mitochondrial activities of the cells, were evaluated after $24 \mathrm{~h}$ exposure. In addition, long term toxicity was evaluated by means of the clonogenic assay which measured the colony forming ability of both the cell lines following an 8 day exposure period.

In addition to the specific goal of establishing the toxicity of the dendrimer series, the study aims to relate the observed toxic response to the systematically varied physicochemical properties of successive generations. Correlations between the observed responses and the structural variations can lay the basis of quantitative structure activity relationships, contributing to the understanding of the fundamentals governing the interactions of nanoparticles and biological systems.

\section{Materials and Methods}

\subsection{Test materials}

Polyamidoamine (PAMAM) dendrimers, G4, G5 and G6, were purchased from Sigma Aldrich Ltd. (Ireland). All the particles have an ethylenediamine core and PAMAM G4, G5 and G6 have 64, 128 and 256 functional primary amino groups on the surface, respectively. The molecular weights of PAMAM G4, G5 and G6 are 14,215 Da, 28,826 Da and 58,048 Da respectively. (http://www.dendritech.com/pamam.html). The nominal diameters of the PAMAM G4, G5 and G6 dendrimers are 4.5, 5.4 and $6.7 \mathrm{~nm}$ respectively. 


\subsection{Reagents}

3-(4,5-dimethylthiazol-2-yl)-2,5-diphenyltetrazolium bromide (MTT) and Neutral Red (NR) were purchased from Sigma Aldrich Ltd. (Ireland). Alamar Blue (AB) was purchased from Biosource (UK). Cell culture media and supplements were purchased from Sigma Aldrich (Ireland) and Bioscience (Ireland). Carbol fuchsin was purchased from BDH (UK).

\subsection{Particle characterization}

\subsubsection{Particle size and zeta potential measurement}

The diameter and zeta potential of the dendrimers were measured using a Malvern Zeta Sizer Nano ZS (Malvern Instruments, Worcestershire, UK). This instrument is equipped with a helium-neon laser $(\lambda=632.8 \mathrm{~nm})$ and measures the dynamic light (back) scattering (DLS) from a suspension at an angle of $173^{\circ}$. It is capable of measuring particles in the size range $0.6 \mathrm{~nm}-6 \mu \mathrm{m}$. The measurements were performed on $20 \mu \mathrm{M}$ dendrimer solutions at $23^{\circ} \mathrm{C}$ in Milli Q distilled water (MQ), PBS, as well as both cell culture media. The $\mathrm{pH}$ of various test media, before and after exposure to PAMAM G4, G5 and G6 dendrimers was measured using an HQ11d Single-Input pH meter (Hach Company, Colorado).

\subsection{Cell Culture}

$\mathrm{HaCaT}$ cells, an immortal non-cancerous human keratinocyte cell line (kindly provided by Prof. Dr. Boukamp, Heidelberg) and SW480 cells (ATCC, CCL-228) a primary adenocarcinoma cell line of the colon were employed for testing. SW480 cells were cultured in Dublecco's Modified Eagle's Meduim Nutrient Mixture F-12 HAM (DMEM) with $2 \mathrm{mM} \mathrm{L-glutamine} \mathrm{supplemented} \mathrm{with} 10 \%$ fetal bovine serum (FBS), $45 \mathrm{IU} \mathrm{ml}^{-1}$ penicillin and $45 \mathrm{IU} \mathrm{ml}^{-1}$ streptomycin at $37^{\circ} \mathrm{C}$ in $5 \% \mathrm{CO}_{2}$. HaCaT cells were cultured in the same cell culture media under the same conditions with the addition of $1 \mu \mathrm{g} / \mathrm{ml}$ hydrocortisone.

\subsection{Preparation of Dendrimer solution}


Dendrimers were received in methanol at concentrations of $7.0 \mathrm{mM}(\mathrm{G} 4), 1.7 \mathrm{mM}$ (G5) and $0.86 \mathrm{mM}$ (G6). The test solutions of dendrimers were prepared by adding the stock solution to the respective cell culture media at $37^{\circ} \mathrm{C}$ under low speed vortex. The concentration ranges used for the cytotoxicity assays with G4, G5 and G6 are listed in Tables 2, 3 and 4 respectively.

\subsection{Cytotoxicity assays}

The AB, NR, MTT and the clonogenic assay were performed for assessment of the cytotoxicity of each generation to the two cell lines. A preliminary or range finding test was conducted to determine the range of concentrations of interest for the definitive test. The definitive test used a concentration range (at least eight concentrations) in which effects were likely to occur, thereby permitting the calculation of the respective Effective Concentrations $\left(\mathrm{EC}_{50}\right)$, No Observed Effect Concentration (NOEC), and Lowest Observed Effect Concentration (LOEC). In all cases, results were compared to an unexposed control, eliminating any dependence of cell line exposures on volumes, well type, seeding efficiency and numbers, exposure times etc. At maximum doses, the cell culture medium contained $0.6 \%$ methanol. As a control, $0.6 \%$ methanol was added to the medium and a negligible $(2.5 \%)$ toxic response was observed.

It should be noted that interferences between nanoparticles and assays have been observed (Casey et al., 2007b, Kroll et al., 2009). This effect is manifest when the particles, such as carbon nanotubes adhere to the cells and are not efficiently removed by repeated washing. The PAMAM dendrimers studied have a positive surface charge and are highly soluble in water. Therefore it is expected that non internalized dendrimers should be efficiently washed off with PBS in the washing step before the cells are exposed to the dyes. Furthermore, MTT and neutral red are also positively charged and therefore, the interaction of dendrimers with the dyes is not expected.

\subsubsection{Alamar blue and Neutral red assay}

For the AB and NR assays, cells were seeded in 96-well microplates (Nunc, Denmark) at a density of $1 \times 10^{5}$ cells $/ \mathrm{ml}$ in $100 \mu 1$ of respective media containing $10 \%$ FBS. After 24 $\mathrm{h}$ of cell attachment, plates were washed with $100 \mu \mathrm{l} /$ well PBS and the cells were treated 
with increasing concentrations of each generation of dendrimer, prepared in 5\% FBS containing media for $24 \mathrm{~h}$. All incubations were performed at $37^{\circ} \mathrm{C}$ in a $5 \% \mathrm{CO}_{2}$ humidified incubator. Six replicate wells were used for each control and test concentrations per microplate.

The AB and NR assays were conducted consecutively on the same set of plates. The AB assay was performed first followed by the NR assay. The assays were carried out according to the manufacturer's instruction. Briefly, control media or test exposures were removed; the cells were rinsed with $\mathrm{PBS}$ and $100 \mu \mathrm{l}$ of $\mathrm{AB} / \mathrm{NR}$ medium $(5 \%[\mathrm{v} / \mathrm{v}]$ solution of $\mathrm{AB}$ and $1.25 \%[\mathrm{v} / \mathrm{v}]$ of NR dye) prepared in fresh media (without FBS or supplements) were added to each well. After $3 \mathrm{~h}$ incubation $\mathrm{AB}$ fluorescence was measured at the respective excitation and emission wavelength of $531 \mathrm{~nm}$ and $595 \mathrm{~nm}$ in a VICTOR ${ }^{3} \mathrm{~V}^{\mathrm{TM}} 1420$ Multilabel Counter (Perkin Elmer, USA). Wells having only AB and media were used as blanks. After measurement, the wells were then washed with PBS and $100 \mu \mathrm{l}$ of NR fixative (50\% ethanol, $49 \% \mathrm{dH}_{2} \mathrm{O}$ and $1 \%$ glacial acetic acid) was added to each well and the plates were shaken at $240 \mathrm{rpm}$ for $10 \mathrm{~min}$. The NR fluorescence was then measured at the excitation and emission wavelength of $531 \mathrm{~nm}$ and $642 \mathrm{~nm}$ respectively in the same instrument. For both assays, mean fluorescent units for the six replicate cultures were calculated for each exposure treatment.

\subsubsection{MTT assay}

A parallel set of plates was set up for the MTT assay and seeded and exposed in an identical manner as described in section 2.6.1. After $24 \mathrm{~h}$ of PAMAM dendrimer exposure, the medium for the control or test exposures was removed, the cells were washed with PBS and $100 \mu 1$ of freshly prepared MTT in media $(5 \mathrm{mg} / \mathrm{ml}$ of MTT in media [without FBS or supplements]) were added to each well. After $3 \mathrm{~h}$ incubation, the medium was discarded and the cells were rinsed with PBS and $100 \mu 1$ of MTT fixative solution (isopropanol with $0.04 \mathrm{~N} \mathrm{HCl}$ ) were added to each well and the plates were shaken at $240 \mathrm{rpm}$ for $10 \mathrm{~min}$. The absorbance was then measured at $595 \mathrm{~nm}$ in a TECAN GENios (Grodig, Austria) plate reader. 


\subsubsection{Clonogenic assay}

The clonogenic assay was developed by Puck and Markus (1956) and further standardized by Franken et al. (2006). Herzog et al. (2007) first described the use of this assay for screening nanomaterial cytotoxicity. The clonogenic assay was performed in 6 well plates (Nunc, Denmark) and each well was seeded with $2 \mathrm{ml}$ of respective $10 \%$ FBS containing media at a cell density of 250 cells $/ \mathrm{ml}$. For both cell lines, the cells were allowed to attach for $12 \mathrm{~h}$, which is shorter than their reported doubling time of $23 \mathrm{~h}$ for HaCaT cells (Boukamp et al., 1988) and 20-24 h for SW480 cells (Tanaka et al., 2002). Therefore it is assumed that predominantly single cells were present at the time of exposure. After $12 \mathrm{~h}$ of cell attachment, plates were washed with $2 \mathrm{ml} /$ well PBS and the cells were treated with increasing concentrations of different generations of dendrimer test solutions prepared in 5\% FBS containing respective media. The plates were then incubated for 8 days. Two replicate wells were used for each control and test concentrations per 6-well plate. Following exposure, the test solution was removed; the cells were washed with PBS and finally fixed and stained with $20 \%$ carbol fuchsin in formalin solution (BDH, Poole, UK). The colonies were then manually counted. The minimum size of a colony was considered to be 50 cells/colony. In all these assays, a solvent control (i.e. $0.6 \%$ methanol in 5\% FBS containing media) was incorporated in parallel to the normal control (i.e., 5\% FBS containing respective media). This solvent control (SC) contained the highest concentration of solvent used in the test solutions.

\subsection{Spectroscopic analysis}

It is reported that some nanoparticles interact and bind with various molecular constituents of cell culture media resulting in a secondary or indirect toxic response by medium depletion (Casey et al., 2007; Casey et al., 2008). UV/visible absorption spectroscopic analysis of different generations of PAMAM dendrimers in respective 5\% FBS supplemented media for SW480 (SW480 media) and HaCaT (HACAT media) cells was performed using a Perkin Elmer Lambda $900 \mathrm{UV} /$ visible/NIR absorption spectrometer. Equal molarities of $15 \mu \mathrm{M}$ of PAMAM G4, G5 and G6 were used for spectroscopic analysis. PAMAM dendrimers were dispersed in cell culture medium and kept at $37^{\circ} \mathrm{C}$ for $24 \mathrm{~h}$ before measurement at RT. 


\subsection{Statistics}

Experiments were conducted in triplicate at least (three independent experiments). Test treatments for each assay (AB, NR, MTT and clonogenic assay) were expressed as percentage of the unexposed control \pm standard deviation (SD). Control values were set at $0 \%$. For all the assays, cytotoxicity was expressed as mean percentage increase relative to unexposed control $\pm \mathrm{SD}$. Cytotoxicity data was fitted to a sigmoidal curve and a four parameter logistic model used to calculate the Effective Concentration of nanomaterial that caused a $50 \%$ inhibition in comparison to untreated controls $\left(\mathrm{EC}_{50}\right) . \mathrm{EC}_{50}$ values are reported $\pm 95 \%$ Confidence Intervals $( \pm 95 \% \mathrm{CI})$. This analysis was performed using Xlfit3 ${ }^{\mathrm{TM}}$, a curve fitting add-on for Microsoft ${ }^{\circledR}$ Excel (ID Business Solutions, UK). Statistical analyses were carried out using paired Student's t-test in Microsoft ${ }^{\circledR}$ Excel where 95\% significance levels were accepted.

\section{Results}

\subsection{Particle size measurement}

The average particle size of the different generations of PAMAM dendrimers (G4, G5 and G6) in the various media are shown in Table 1. In PBS a monomodal size distribution was observed and the values compare well to those quoted by the manufacturers (http://www.dendritech.com/pamam.html). In the case of the cell culture media, the comparatively higher values may indicate an interaction with components of the media as has been recently observed in fish cell culture media (Naha et al, 2009b). It is notable, however, that although significantly higher values are observed for G4 and G6 in both media, no significant difference was recorded for G5 in either medium.

\subsection{Zeta potential measurement}

The zeta potential of each dendrimer was measured in MQ water and in each of the test media employed and these values are shown graphically in Figure 2. The error bars of Figure 2 indicate the variability in the measured value of Zeta potential. Although there are some overlaps of the extremes, consistent trends are observed in all media. In MQ, the zeta potential is positive and increases monotonically with increasing particle 
generation. This is consistent with the increased number of positively charged $\mathrm{NH}_{2}$ surface groups. In the cell culture media, however, the zeta potential is negative, and is seen to become less so with increasing generation. As the zeta potential is dependent on the interface between the particle and the dispersion medium, a change is zeta potential is not surprising. However, the change in zeta potential may also be indicative of an interaction of the nanoparticles with components of the medium. This is consistent with the increase in the diameter in cell culture media as measured by DLS (Table 1).

\subsection{Spectroscopy}

Particle size and zeta potential measurements indicated an interaction of dendrimer nanoparticles with components of the cell culture medium. Such an interaction was also reported for dendrimers in fish cell culture media (Naha et al., 2009b) and for single walled carbon nanotubes in A549 culture medium, giving rise to an indirect toxic response as a result of medium depletion (Casey et al, 2008). It has been demonstrated that such an interaction can be characterized using UV/visible absorption spectroscopy, changes to the characteristic features associated with the components of the medium indicating adsorption to the nanoparticles.

The UV-Visible absorption spectrum of the DMEM medium shows characteristic peaks at $\sim 270, \sim 360, \sim 440$ and $\sim 560 \mathrm{~nm}$ as shown in Figure $3 \mathrm{a}$. The feature at $\sim 360 \mathrm{~nm}$ and $\sim 40 \mathrm{~nm}$ can be attributed to riboflavin (Posadaz et al., 2000; Zirak et al., 2005), and/or plasma bilirubin (Aoyagi et al., 1979, Berk et al., 1969, Zucker et al., 2004), whereas the feature at $\sim 560 \mathrm{~nm}$ can be assigned to the phenol red $\mathrm{pH}$ indicator within the medium. At $\sim 270 \mathrm{~nm}$, there are contributions from the range of amino acids and other molecular components contained within the medium. Upon addition of FBS, in HaCaT and SW480, a further feature at $\sim 410 \mathrm{~nm}$ evolves and the feature at $\sim 270 \mathrm{~nm}$ increases significantly. These features have been associated with the FBS absorption (Casey et al., 2008). Most notably, upon addition of the FBS to the DMEM medium, there is a visible colour change manifest spectroscopically as a significant decrease of the characteristic absorption feature of the phenol red $\mathrm{pH}$ indicator at $\sim 560 \mathrm{~nm}$ indicating that the additional proteins affect a change in the $\mathrm{pH}$ of the medium. This was indeed observed, the $\mathrm{pH}$ of the medium decreasing from 7.88 (DMEM) to $7.48(\mathrm{HaCaT})$ and 7.73 (SW480) as a result of 
the addition of FBS. In the case of the $\mathrm{HaCaT}$ medium, the additional hydrocortisone results in a further decrease in the $\mathrm{pH}$ and the phenol red absorption.

Upon addition of the dendrimer particles to the cell culture media, a visible colour change was also observed. Figure $3 \mathrm{~b}$ and $3 \mathrm{c}$ shows the absorption spectra of $\mathrm{HaCaT}$ and SW480 media respectively, with and without the dendrimer particles added. The phenol red absorption at $\sim 560 \mathrm{~nm}$ was found to increase, the degree of increase following the sequence $\mathrm{G} 4<\mathrm{G} 5<\mathrm{G} 6$. This is essentially a reversal of the changes observed in the pure medium DMEM upon addition of the FBS and hydrocortisone (Figure 3a). The observed colour and spectroscopic changes can be associated with changes in the $\mathrm{pH}$ of the medium. Upon addition of the dendrimer nanoparticles to the media, the $\mathrm{pH}$ was seen to recover. For HaCaT medium the pH increases for PAMAM G4 (7.58), G5 (7.63) and G6 (7.73), whereas for SW480 media, the pH recovered to 7.80 for PAMAM G4, 7.85 for G5 and 7.95 for G6.

Also notable in Figure $3 \mathrm{~b}$ and $3 \mathrm{c}$ are the changes to the spectral feature at $\sim 410 \mathrm{~nm}$, associated with the FBS. There is a progressive reduction of the absorbance from that observed in the pure medium in the sequence G4>G5>G6. The reduction of the absorbance feature associated with the FBS and the concurrent reversal of the $\mathrm{pH}$ changes caused by the addition of the FBS to the pure medium point towards an interaction of the particles with the FBS by adsorption, effectively changing the absorbance contributions. This represents a significant change to the effective composition of the medium and is consistent with the formation of a so-called "protein corona" around the nanoparticle as previously reported for nanoparticles in biological media (Cedervall et al., 2007; Lynch and Dawson., 2008; Lundqvist et al., 2008). It is generally understood that the interaction is a physisorption of the medium constituents onto the surface of the nanoparticles resulting in a reduction of the effective medium composition. While the addition of FBS has previously been shown to reduce the toxicity of nanoparticles (Casey et al, 2007) the interaction with the medium can result in a depletion of nutrients resulting in an indirect toxic response (Casey et al, 2008). 


\subsection{Cytotoxicity}

For all assays, a dose dependent response was observed and an $\mathrm{EC}_{50}$, NOEC and LOEC value calculated. Cytotoxicity data for the PAMAM G4 dendrimer and the HaCaT and SW480 cells are presented in Table 2 . In the clonogenic assay the average plating efficiencies for the $\mathrm{HaCaT}$ and SW480 cells were $42 \%$ and $77 \%$ respectively. Cytotoxicity data for the PAMAM G5 dendrimer and the HaCaT and SW480 cells are presented in Table 3. As with the G4 dendrimer, a dose dependent response was observed for all endpoints. A dose dependent response was also observed for all endpoints for the PAMAM G6 dendrimer and the cytotoxicity data is presented in Table 4. Figure 4 summarises the generation dependent toxic response recorded for each assay, highlighting the structural dependence of the response and the different sensitivities of the different end points.

\section{Discussion}

The cytotoxicity endpoints employed in this study revealed a structurally dependent toxic response for both cell lines, PAMAM G4 being the least toxic, G6 the most. The most sensitive assay for all dendimers and both cell lines was the clonogenic assay with the exception of the exposure of SW480 cells to G5, for which the MTT assay was recorded to be slightly more sensitive, although there is no significant statistical difference to the clonogenic assay response. The particle exposure time in the clonogenic assay is longer than other assays, i.e., 8 days, indicating that chronic effects are more severe than acute effects. The MTT assay was found to be the most sensitive of the short term (i.e. $24 \mathrm{~h}$ exposure) assays employed, while $\mathrm{AB}$ was intermediate. The interpretation of the action of the Alamar Blue (AB) assay is somewhat varied. One report has suggested that it may indicate the early inhibition of cytoplasmic metabolism and cell growth (O'Brien et al, 2000) while another suggests that it indicates the inhibition of mitochondrial metabolism (De Fries and Mitsuhashi, 1995). Therefore while the MTT assay only indicates the mitochondrial metabolic activity of cells, the $\mathrm{AB}$ assay may indicate changes to the cell growth and cytoplasmic metabolic activity as well as mitochondrial metabolic activity. The NR assay was found to be the least sensitive for all dendrimers for both the cell lines tested. 
The data also demonstrated that SW480 cells were more sensitive than HaCaT cells. One significant difference between the two cell lines employed is their antioxidant levels with HaCaT cells having 150 times more GSH than SW480 cells (Snow et al., 2005, Nakagawa et al., 2002) which may point towards a significant role of reactive oxygen species in the toxic mechanism.

Physio-chemical characters of nanoparticles play a significant role in their effect on biological systems (Oberdörster et al., 2000; Donaldson et al., 2004). The principal parameters of nanoparticles are their shape (including aspect ratios where appropriate), size, and the morphological sub-structure of the substance. The chemical composition and the intrinsic toxicological properties of the chemical are also of importance for toxicity of particles (Renwick et al., 2004). The zeta potential of the particle has been reported to play a significant role in its interaction with different biomolecules (Vila et al., 2002) and the change in the zeta potential in the exposure medium has been shown to correlate well with toxic response (Naha et al., 2009a, Naha et al., 2009b)

The diameters of the dendrimers were measured in PBS, HaCaT and SW480 media. In the case of the neutral environment of MQ, the measured zeta potential was seen to scale approximately linearly with the dendrimer surface area, and sub-linearly with the number of $\mathrm{NH}_{2}$ groups per generation (Figure 2). In the case of both cell culture media, however, no correlation was observed between the measured zeta potential and the dimensions of the dendrimer generations (data not shown). The zeta potential and indeed the surface of the nanoparticles has been significantly changed due to interaction with the medium, however, and Figure 5 illustrates for the example of the SW480 medium that this change, expressed in terms of zeta potential, is related to the particle surface area. Although a linear dependence is indicated by the figure, it should be noted that evaluation over a wider range of dendrimer generation is required to determine the exact nature of the correlation.

Similarly, in terms of toxic response, although the calculated $\mathrm{EC}_{50}$, values for all assays and both cell lines, follow the general trend of increasing toxicity with increasing dendrimer generation (with the exception of G5 for the MTT assay in the SW480 cell line), the trend is not linear for either the measured particle diameter or surface area (data not shown). Toxicity is however inversely proportional to $\mathrm{EC}_{50}$ and the best correlation is 
observed between the inverse $\mathrm{EC}_{50}$ and the surface area, as shown in Figure 6 for the example of the AB assay with the SW480 cell line. Again, the linear representation is for visual purposes only. The ratio between the molecular weights of PAMAM G4:G5:G6 is $1: 2: 4$. Therefore, weight per volume of the dendrimers in solution increases in the order $\mathrm{G} 4<\mathrm{G} 5<\mathrm{G} 6$. However, the number of amine groups per unit weight does not change significantly. The ratios between the number of amine group per surface area in G4, G5 and G6 are 1.49, 0.88, and 1.05 respectively, which does not correlate the observed trends of toxic response. The number of amine groups per dendrimer increases linearly with generation in the order $\mathrm{G} 4<\mathrm{G} 5<\mathrm{G} 6$, which does correlate well with the toxic response.

As shown in Figure 7 for the example of the $\mathrm{HaCaT}$ cell line, the calculated $\mathrm{EC}_{50}$ values correlate well with the measured zeta potential for the dendrimers for all assays. The measured negative zeta potential, by comparison to that of the neutral MQ environment is not an intrinsic property of the dendrimer particles, however, but a result of adsorption of protein supplement from the medium. Furthermore, the trend of Figure 7 is negative, indicating that decreasing effective surface charge affects a greater toxic response, which is counter intuitive. The change in the zeta potential as a result of interaction with the medium is also well correlated with the toxic response for all assays, as shown in Figure 8. A similar behaviour has been observed for $N$-isopropylacrylamide / $N$-tertbutylacrylamide copolymer nanoparticles (Naha et al., 2009a) and in ecotoxicological studies of PAMAM nanoparticles (Naha et al. 2009b). Such an interaction of the nanoparticles with the components of the cell culture medium has been demonstrated to elicit a secondary or indirect toxic response in the case of single walled carbon nanotubes (Casey et al., 2007, 2008) and it is probable that there are similar contributions to the toxic response observed here. The interaction appears to be a selective and dynamic physisorption of medium constituents (Lynch and Dawson, 2008.) and as such the response may be dependent on the medium employed. The UV/visible absorption spectroscopic analysis does indicate that the additional hydrocortisone in the HaCaT medium may play a role in the interaction of the dendrimer nanoparticles with the medium. It is unknown as yet as to how such an effect would translate from in vitro to in vivo situations. 


\section{Conclusions}

Spectroscopic evidence suggests that there is significant protein adsorption by the particles in the cell growth media and that this effect increases with dendrimer generation (Figure 3). This protein adsorption from the medium is also manifest in a dramatic change in the zeta potential and therefore surface properties of the particles. The adsorption also implies a significant change to the effective composition of the medium, and although the toxic response of all assays can be correlated to the zeta potential of the dendrimers, the toxic response can be best understood in terms of an indirect effect as a result of medium depletion. The SW480 cell lines are seen to be most sensitive and the clonogenic assay shows the strongest response indicating potentially chronic responses.

Although the best correlation of the physico-chemical properties with the toxicity data indicates an indirect response, a direct interaction with and possibly internalisation by the cells cannot be ruled out and studies are ongoing to further elucidate the contributions of such interactions. In addition a consistent trend was seen in the HaCaT cell line using the NR assay. For each dendrimer tested using this assay a hormetic response was observed whereby the assay showed a higher stimulatory/survival response in comparison to the control in the lower concentration region although at higher concentrations a toxic response was observed. Current research is therefore being conducted to further investigate this phenomenon in terms of elucidating the underlying mechanism/s driving this response.

\section{Acknowledgements}

This work was conducted under the framework of the INSPIRE programme, funded by the Irish Government's Programme for Research in Third Level Institutions, Cycle 4, National Development Plan 2007-2013, supported by the European Union Structural Fund. 


\section{References}

- Aoyagi, Y., Ikenaka, T., Ichida, F., 1979. a-Fetoprotein as a Carrier Protein in Plasma and Its Bilirubin-binding Ability. Cancer Research 39, 3571 -3574.

- Basak, P. and Adhikari, B., Published online: 1 July 2008. Poly (vinyl alcohol) hydrogels for $\mathrm{pH}$ dependent colon targeted drug delivery. Journal of Materials Science: Materials in Medicine.

- Berk, P.D., Howe, R.B., Bloomer J.R., Berlin, N.I., 1969. Studies of Bilirubin Kinetics in Normal Adults. The Journal of Clinical Investigation 48, 2176-2190.

- Boukamp, P., Petrussevska, R.T., Breitkreutz, D., Hornung, J., Markham, A., Fusenig, N.E., 1988. Normal Human keratinization in a spontaneously immortalized aneuploid human keratinocyte cell line. Journal of Cell Biol. 106, 761-771.

- Casey, A., Herzog, E., Lyng, F. M., Byrne, H. J., Chambers, G., Davoren, M., 2008. Single walled carbon nanotubes induce indirect cytotoxicity by medium depletion in A549 lung cells. Toxicol. Lett. 179, 78-84.

- Casey, A., Davoren, M., Herzog, E., Lyng, F. M., Byrne, H. J., Chambers, G., 2007. Probing the interaction of single walled carbon nanotubes within cell culture medium as a precursor to toxicity testing. Carbon 45, 34-40.

- Casey, A., Herzog, E., Davoren, M., Lyng, F.M., Byrne, H.J., Chambers, G., 2007b. Spectroscopic analysis confirms the interactions between single walled carbon nanotubes and various dyes commonly used to assess cytotoxicity. Carbon 45, 1425-1432.

- Cedervall, T., Lynch, I., Lindman, S., Berggård, T., Thulin, E., Nilsson, H., Dawson, K., Linse, S., 2007. Understanding the nanoparticle-protein corona using methods to quantify exchange rates and affinities of proteins for nanoparticles. PNAS 104, 2050-2055.

- De Fries, R., Mitsuhashi, M., 1995 Quantification of mitogen induced human lymphocyte proliferation: Comparison of alamarblue ${ }^{\mathrm{tm}}$ assay to ${ }^{3} \mathrm{~h}$-thymidine incorporation assay, Journal of Clinical Laboratory Analysis 9, 89 - 95.

- Dear, J.W., Kobayashi, H., Brechbiel, M.W., Star, R.A. 2006. Imaging Acute Renal Failure with Polyamine Dendrimer-Based MRI Contrast Agents. Nephron Clin Pract 103, c45-c49.

- Dendritech website: http://www.dendritech.com/pamam.html .

- Donaldson, K., Stone, V., Tran, C.L., Kreyling, W., Borm P.J.A., 2004. Nanotoxicology. Occup Environ Med 61, 727-728.

- Franken, N.A.P., Rodermond, H.M., Stap, J., Haveman, J., Bree, C.V., 2006. Clonogenic assay of cells in vitro. Nature Protocols 1, 2315 - 2319.

- Geever, L. M., Cooney, C. C., Lyons, J. G., Kennedy, J. E., Nugent, M. J., Devery, S., Higginbotham, C. L., 2008. Characterisation and controlled drug release from novel drug-loaded hydrogels. Eur J Pharm Biopharm 69, 1147-1159.

- George, P.M., Lyckman, A.W., LaVan, D.A., Hegde, A., Leung, Y., Avasare, R., Testa, C., Alexander, P.M., Langer, R., Sur, M., 2005. Fabrication and biocompatibility of polypyrrole implants suitable for neural prosthetics. Biomaterials 26, 3511-3519. 
- Guillot-Nieckowski, M., Eisler, S., Diederich, F., 2007. Dendritic vectors for gene transfection. New J. Chem. 31, 1111-1127.

- Heiden, T.C.K., Dengler, E., Kao, W. J., Heideman, W., Richard E. Peterson, R. E., 2007. Developmental toxicity of low generation PAMAM dendrimers in zebrafish. Toxicology and Applied Pharmacology 225, 70-79.

- Herzog, E., Casey, A., Lyng, F.M., Chambers, G., Byrne, H.J., Davoren, M., 2007. A new approach to the toxicity testing of carbon-based nanomaterials-The clonogenic assay. Toxicology Letters, 174, 49-60.

- Hong, S., Bielinska, A.U., Mecke, A., Keszler, B., Beals, J.L., Shi, X., Balogh, L., Orr, B.G., Baker, J.R., Holl, M.M.B., 2004. Interaction of Poly(amidoamine) Dendrimers with Supported Lipid Bilayers and Cells: Hole Formation and the Relation to Transport. Bioconjugate Chem. 15, 774-782.

- Jevprasesphant, R., Penny, J., Jalal, R., Attwood, D., McKeown, N. B., D'Emanuele, A., 2003. The influence of surface modification on the cytotoxicity of PAMAM dendrimers. International Journal of Pharmaceutics 252 263-266.

- Kikuchi, T., Saito, R., Sugiyama, S., Yamashita, Y., Kumabe, T., Krauze, M., Bankiewicz, K., Tominaga, T., 2008. Convection-enhanced delivery of polyethylene glycol-coated liposomal doxorubicin: characterization and efficacy in rat intracranial glioma models. Journal of neurosurgery 109, 867-873.

- Klajnert, B., Sadowska, M., Bryszewska, M., 2004. The effect of polyamidoamine dendrimers on human erythrocyte membrane acetylcholinesterase activity. Bioelectrochemistry 65, 23-26

- Klajnerta, B., StanisClawskaa, L., Bryszewskaa, M., PaClecz, B., 2003. Interactions between PAMAM dendrimers and bovine serum albumin. Biochimica et Biophysica Acta 1648, 115-126.

- Kreuter, J., 2000. Poly(Methyl Methacrylate) Nanoparticles As Vaccine Adjuvants. Methods in Molecular Medicine 42, 105-119

- Kroll, A., Pillukat, M.H., Hahn, D., Schnekenburger, J., 2009 Current in vitro methods in nanoparticle risk assessment: Limitations and challenges. European Journal of Pharmaceutics and Biopharmaceutics 72, 370-377.

- Leroueil, P.R., Berry, S.A., Duthie, K., Han, G., Rotello V.M., McNerny, D.Q., Baker, J.R., Orr, B.G., Holl, M.M.B., 2008. Wide varieties of cationic nanoparticles induce defects in supported lipid bilayers. Nano Lett. 8, 420-424.

- Lundqvist, M., Stigler, J., Elia, G., Lynch, I., Cedervall, T., Dawson, K., 2008. Nanoparticle size and surface properties determine the protein corona with possible implications for biological impacts. PNAS 105, 14265-14270.

- Lynch, I., Dawson, K., 2008. Protein-nanoparticle interactions. Nanotoday 3, 4047.

- Malik, N.,Wiwattanapatapee, R., Klopsch R., Lorenz, K., Frey, H., Weener, J.W., Meijer, E.W., Paulus, W., Duncan, R., 2000. Dendrimers: - Relationship between structure and biocompatibility in vitro, and preliminary studies on the biodistribution of ${ }^{125}$ I-labelled polyamidoamine dendrimers in vivo. Journal of Controlled Release 65, 133-148. 
- Mishra, R. K., Datt, M., Banthia, A. K., 2008. Synthesis and characterization of pectin/PVP hydrogel membranes for drug delivery system. AAPS PharmSciTech 9, 395-403.

- Na, M., Yiyun, C., Tongwen, X., Yang, D., Xiaomin, W., Zhenwei, L., Zhichao, C., Guanyi, H., Yunyu, S., Longping, W., 2006. Dendrimers as potential drug carriers. Part II. Prolonged delivery of ketoprofen by in vitro and in vivo studies. European Journal of Medicinal Chemistry 41, 670-674

- Naha, P. C., Casey, A., Tenuta, T., Lynch, I., Dawson, K. A., Byrne, H. J., Davoren, M. 2009a. Preparation, Characterization of NIPAM and NIPAM/BAM Copolymer Nanoparticles and their Acute Toxicity Testing using an Aquatic test battery. Aquat. Toxicol. 92, 146-154.

- Naha, P.C., Davoren, M., Casey, A., Byrne H.J., 2009b Multi trophic Eco toxicological study of PAMAM dendrimers -towards quantitative structure activity relationships. Communicated.

- Nakagawa Y.,, Akao Y., Morikawa H., Hirata I., Katsu K., Naoe T., Ohishi N., Yagi K., 2002. Arsenic trioxide-induced apoptosis through oxidative stress in cells of colon cancer cell lines, Life Sciences 70, 2253-2269.

- Noda, T., Iwakirl, R., Fujimotp, K., Aw, T.Y., 2001. Induction of mild intracellular redox imbalance inhibits proliferation of CaCo-2 cells. The FASEB Journal 15, 2131-2139.

- Oberdörster, G., Finkelstein, J.N., Johnston, C., Gelein, R., Cox, C., Baggs, R., Elder, A.C.P., 2000. Acute pulmonary effects of ultrafine particles in rats and mice. HEI Research Report 96. Health Effects Institute, www.healtheffects.org/pubs-research.htm

- O'Brien, J., Wilson, I., Orton, T., Pognan, F., 2000. Investigation of the Alamar Blue (resazurin) fluorescent dye for the assessment of mammalian cell cytotoxicity, Eur. J. Biochem. 267, 5421-5426.

- Posadaz, A., Sanchez, E., Gutierrez, M.I., Calderon, M., Bertolotti, S., Biasutti, M.A., Garcia, N.A., 2000 Riboflavin and rose Bengal sensitised photooxidation of sulfathiazole and succinylsulfathiazole kinetic study and microbiological implications. Dyes and Pigments 45, 219-228.

- Puck, T.T., Marcus, P.L., 1956. Action of X-rays on mammalian cells. $J$ Exp Med. 103, 653-666.

- Renwick, L.C., Brown, D., Clouter, A. and Donaldson, K., 2004. Increased inflammation and altered macrophagfe chemotactic responses caused by two ultrafine particle types. Occup Environ Med 61, 442-446.

- Robert, J.C., Bhalgat, M.K., Zera, R.T., 1996. Preliminary biological evaluation of polyamidoamine (PAMAM) Starburst dendrimers. Journal of Biomedical Materials Research 30, 53-65.

- Snow E.T., Sykora P., Durham T.R., Klein C.B., 2005. Arsenic, mode of action at biologically plausible low doses: What are the implications for low dose cancer risk? Toxicology and Applied Pharmacology 207, S557 - S564. 
- Storrie, H., Mooney, D.J., 2006. Sustained delivery of plasmid DNA from polymeric scaffolds for tissue engineering. Advanced Drug Delivery Reviews 58 $500-514$.

- Swanson, S. D., Kukowska-Latallo, J. F., Patri, A. K., Chen, C., Ge, S., Cao, Z., Kotlyar, A., East, A. T., Baker, J. R., 2008. Targeted gadolinium-loaded dendrimer nanoparticles for tumor-specific magnetic resonance contrast enhancement. International journal of nanomedicine 3, 201-210.

- Tanaka, M., Kijima, H., Itoh, J., Matsuda, T., Tanaka, T., 2002. Impaired expression of a human septin family gene Bradeion inhibits the growth and tumorigenesis of colorectal cancer in vitro and in vivo. Cancer gene therapy $\mathbf{9}$, 483-488.

- US Patent 5474783 - Solubility parameter based drug delivery system and method for altering drug saturation concentration. US Patent Issued on December 12, 1995.

- US Patent 5902603- Polyurethane hydrogel drug reservoirs for use in transdermal drug delivery systems, and associated methods of manufacture and use. US Patent Issued on May 11, 1999.

- Vila, A., Sanchez, A., Tob'10, M., Calvo, P., Alonso, M. J., 2002. Design of biodegradable particles for protein delivery. Journal of Controlled Release 78, $15-24$.

- Yiyun, C., Tongwen, X., Rongqiang, F., 2005. Polyamidoamine dendrimers used as solubility enhancers of ketoprofen. European Journal of Medicinal Chemistry 40, 1390-1393.

- Zhao, H., Yung, L. Y., 2008. Selectivity of folate conjugated polymer micelles against different tumor cells. International Journal of Pharmaceutics 349, 256268.

- Zhou, J., Wu, J., Hafdi, N., Behr, J. P., Erbacher, P., Peng, L., 2006. PAMAM dendrimers for efficient siRNA delivery and potent gene silencing. Chemical communications (Cambridge, England), 2362-2364.

- Zirak, P., Penzkofer, A., Schiereis, T., Hegemann, P., Jung, A.; Schlichting, I., 2005. Absorption and fluorescence spectroscopic characterisation of BLUF domain of AppA from Rhodobacter sphaeroides. Chemical Physics 315, 142 154.

- Zucker, S.D., Horn, P.S., Sherman, K.E., 2004. Serum bilirubin levels in the U.S. population: gender effect and inverse correlation with colorectal cancer. Hepatology 40, 827-35. 


\section{List of Table legends}

Table 1. Diameters of PAMAM dendrimers of generations G4, G5 and G6 in PBS, SW480 and HaCaT media and the reported values by the manufacturer in their website http://www.dendritech.com/pamam.html.

Table 2. Cytotoxicity data for PAMAM G4 on HaCaT and SW480 cell lines

Table 3. Cytotoxicity data for PAMAM G5 on HaCaT and SW480 cell lines

Table 4. Cytotoxicity data for PAMAM G6 on HaCaT and SW480 cell lines 
Table 1

\begin{tabular}{|c|c|c|c|}
\hline $\begin{array}{c}\text { Different Test } \\
\text { Media }\end{array}$ & $\begin{array}{c}\text { PAMAM G-4 } \\
\text { Size in } \mathrm{nm} \\
\text { (Diameter) }\end{array}$ & $\begin{array}{c}\text { PAMAM G-5 } \\
\text { Size in } \mathrm{nm} \\
\text { (Diameter) }\end{array}$ & $\begin{array}{c}\text { PAMAM G-6 } \\
\text { Size in } \mathrm{nm} \\
\text { (Diameter) }\end{array}$ \\
\hline PBS & $3.7 \pm 0.9$ & $6.8 \pm 0.6$ & $8.8 \pm 1.3$ \\
\hline HaCaT Media & $6.2 \pm 0.3$ & $6.5 \pm 0.1$ & $10.2 \pm 0.5$ \\
\hline SW480 Media & $5.0 \pm 0.3$ & $6.1 \pm 0.2$ & $11.2 \pm 0.7$ \\
\hline $\begin{array}{c}\text { Manufacturer's } \\
\text { reported value }\end{array}$ & 4.5 & 5.4 & 6.7 \\
\hline
\end{tabular}


Table 2

\begin{tabular}{|c|c|c|c|c|}
\hline $\begin{array}{l}\text { PAMAM G4 } \\
\text { [concentration range used }(\mu \mathrm{M})]\end{array}$ & $\begin{array}{l}\mathrm{EC}_{50}(\mu \mathrm{M}) \\
{[\text { Confidence Interval] }}\end{array}$ & $\mathrm{r}^{2}$ & $\begin{array}{l}\text { NOEC } \\
(\mu \mathrm{M})\end{array}$ & $\begin{array}{l}\text { LOEC } \\
(\mu \mathrm{M})\end{array}$ \\
\hline \multicolumn{5}{|l|}{ HaCaT Cells } \\
\hline $\begin{array}{l}\text { Alamar blue assay } \\
{[0.01-21.1]}\end{array}$ & 16.35 [13.69-19.02] & 0.96 & 0.01 & 0.14 \\
\hline $\begin{array}{l}\text { Neutral red assay } \\
{[0.01-21.1]}\end{array}$ & $23.16[16.43-29.88]$ & 0.64 & 19.7 & 21.1 \\
\hline $\begin{array}{l}\text { MTT assay } \\
{[0.01-21.1]}\end{array}$ & $3.21[2.89-3.52]$ & 0.99 & 0.14 & 0.7 \\
\hline $\begin{array}{l}\text { Clonogenic assay } \\
{[0.01-21.1]}\end{array}$ & $2.63[1.78-3.47]$ & 0.93 & $\leq 0.01$ & 0.01 \\
\hline \multicolumn{5}{|l|}{ SW480 Cells } \\
\hline $\begin{array}{l}\text { Alamar blue assay } \\
{[0.01-7.03]}\end{array}$ & $8.3[7.26-9.33]$ & 0.99 & 0.01 & 0.14 \\
\hline $\begin{array}{l}\text { Neutral red assay } \\
{[0.01-7.03]}\end{array}$ & $10.8[8.57-13.03]$ & 0.98 & 0.14 & 0.7 \\
\hline $\begin{array}{l}\text { MTT assay } \\
{[0.01-7.03]}\end{array}$ & $1.44[1.28-1.6]$ & 0.99 & 0.14 & 0.7 \\
\hline $\begin{array}{l}\text { Clonogenic assay } \\
{[0.01-14.07]}\end{array}$ & $1.43[1.27-1.59]$ & 0.99 & $\leq 0.01$ & 0.01 \\
\hline
\end{tabular}


Table 3

\begin{tabular}{|c|c|c|c|c|}
\hline $\begin{array}{l}\text { PAMAM G5 } \\
\text { [concentration range used }(\mu \mathrm{M})]\end{array}$ & $\begin{array}{l}\mathrm{EC}_{50}(\mu \mathrm{M}) \\
\text { [Confidence Interval] }\end{array}$ & $\mathrm{r}^{2}$ & $\begin{array}{l}\text { NOEC } \\
(\mu \mathrm{M})\end{array}$ & $\begin{array}{l}\text { LOEC } \\
(\mu \mathrm{M})\end{array}$ \\
\hline \multicolumn{5}{|l|}{ HaCaT Cells } \\
\hline $\begin{array}{l}\text { Alamar blue assay } \\
{[0.03-5.2]}\end{array}$ & $1.89[1.35-2.43]$ & 0.96 & $\leq 0.03$ & 0.03 \\
\hline $\begin{array}{l}\text { Neutral red assay } \\
{[0.03-5.2]}\end{array}$ & $5.75[3.98-7.52]$ & 0.92 & 2.6 & 3.47 \\
\hline $\begin{array}{l}\text { MTT assay } \\
{[0.03-5.2]}\end{array}$ & $1.07[0.64-1.5]$ & 0.94 & 0.03 & 0.35 \\
\hline $\begin{array}{l}\text { Clonogenic assay } \\
{[0.03-5.2]}\end{array}$ & $0.57[0.37-0.77]$ & 0.97 & 0.03 & 0.35 \\
\hline \multicolumn{5}{|l|}{ SW480 Cells } \\
\hline $\begin{array}{l}\text { Alamar blue assay } \\
{[0.03-5.2]}\end{array}$ & $3.12[2.64-3.59]$ & 0.98 & $\leq 0.03$ & 0.03 \\
\hline $\begin{array}{l}\text { Neutral red assay } \\
{[0.03-5.2]}\end{array}$ & $4.33[3.89-4.76]$ & 0.98 & $\leq 0.03$ & 0.03 \\
\hline $\begin{array}{l}\text { MTT assay } \\
{[0.03-5.2]}\end{array}$ & $0.37[0.18-0.55]$ & 0.95 & $\leq 0.03$ & 0.03 \\
\hline $\begin{array}{l}\text { Clonogenic assay } \\
{[0.03-5.2]}\end{array}$ & $0.41[0.39-0.42]$ & 0.99 & 0.03 & 0.35 \\
\hline
\end{tabular}


Table 4

\begin{tabular}{|c|c|c|c|c|}
\hline $\begin{array}{l}\text { PAMAM G6 } \\
\text { [concentration range used }(\mu \mathrm{M})]\end{array}$ & $\begin{array}{l}\mathrm{EC}_{50}(\mu \mathrm{M}) \\
\text { [Confidence Interval] }\end{array}$ & $\mathrm{r}^{2}$ & $\begin{array}{l}\text { NOEC } \\
(\mu \mathrm{M})\end{array}$ & $\begin{array}{l}\text { LOEC } \\
(\mu \mathrm{M})\end{array}$ \\
\hline \multicolumn{5}{|l|}{ HaCaT Cells } \\
\hline $\begin{array}{l}\text { Alamar blue assay } \\
{[0.01-5.168]}\end{array}$ & $1.30[1-1.59]$ & 0.97 & $\leq 0.01$ & 0.01 \\
\hline $\begin{array}{l}\text { Neutral red assay } \\
{[0.01-5.168]}\end{array}$ & $3.17[2.38-3.96]$ & 0.94 & 1.55 & 2.58 \\
\hline $\begin{array}{l}\text { MTT assay } \\
{[0.01-5.168]}\end{array}$ & $1.02[0.92-1.13]$ & 0.99 & 0.01 & 0.52 \\
\hline $\begin{array}{l}\text { Clonogenic assay } \\
{[0.01-5.168]}\end{array}$ & $0.19[0.14-0.25]$ & 0.98 & 0.01 & 0.1 \\
\hline \multicolumn{5}{|l|}{ SW480 Cells } \\
\hline $\begin{array}{l}\text { Alamar blue assay } \\
{[0.01-5.168]}\end{array}$ & $1.56[1.23-1.88]$ & 0.96 & 0.52 & 1.03 \\
\hline $\begin{array}{l}\text { Neutral red assay } \\
{[0.01-5.168]}\end{array}$ & $1.87[1.46-2.27]$ & 0.96 & 0.52 & 1.03 \\
\hline $\begin{array}{l}\text { MTT assay } \\
{[0.01-5.168]}\end{array}$ & $1.16[0.76-1.56]$ & 0.95 & 0.52 & 1.03 \\
\hline $\begin{array}{l}\text { Clonogenic assay } \\
{[0.01-5.168]}\end{array}$ & $0.18[0.15-0.2]$ & 0.99 & 0.01 & 0.1 \\
\hline
\end{tabular}




\section{List of Figure legends}

Figure 1. Schematic structure of Generation 4 (G4) Poly (amidoamine) dendrimer nanoparticle (Klajnerta et al., 2003)

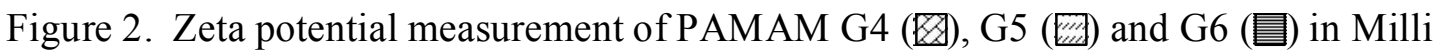
Q (MQ), SW480 and HaCaT media.

Figure 3. Medium interaction study of PAMAM (G4, G5 and G6) dendrimers in HACAT and SW480 media by UV-Visible absorption spectroscopy. a). represents the UV-Visible absorption spectra of DMEM, HACAT and SW480 media. b). represents the UV-Visible absorption spectra of HACAT media with PAMAM (G4, G5 and G6) dendrimers. c). represents UV-Visible absorption spectra of SW480 media with PAMAM (G4, G5 and G6) dendrimers.

Figure 4. $\mathrm{EC}_{50}$ of- PAMAM G4, G5 and G6 for HaCaT cells and SW480 cells.

Figure 5. Surface area vs. change in zeta potential in SW480 media of PAMAM G4, G5 and G6.

Figure 6. Inverse $\mathrm{EC}_{50}$ in $\mathrm{AB}$ assay in SW480 cells vs. surface area of PAMAM G4, G5 and G6 measured in PBS.

Figure 7. $\mathrm{EC}_{50}$ in different assays vs. zeta potential of dendrimers- a) $\mathrm{EC}_{50}$ in $\mathrm{HaCaT}$ cells and zeta potential measured in $\mathrm{HaCaT}$ media b) $\mathrm{EC}_{50}$ in $\mathrm{SW} 480$ cells and zeta potential measured in SW480 media.

Figure $8 . \mathrm{EC}_{50}$ in different assays vs. change in zeta potential of dendrimers- a) $\mathrm{EC}_{50}$ in $\mathrm{HaCaT}$ cells and change in zeta potential measured in $\mathrm{HaCaT}$ media b) $\mathrm{EC}_{50}$ in $\mathrm{SW} 480$ cells and change in zeta potential measured in SW480 media. 
Figure 1

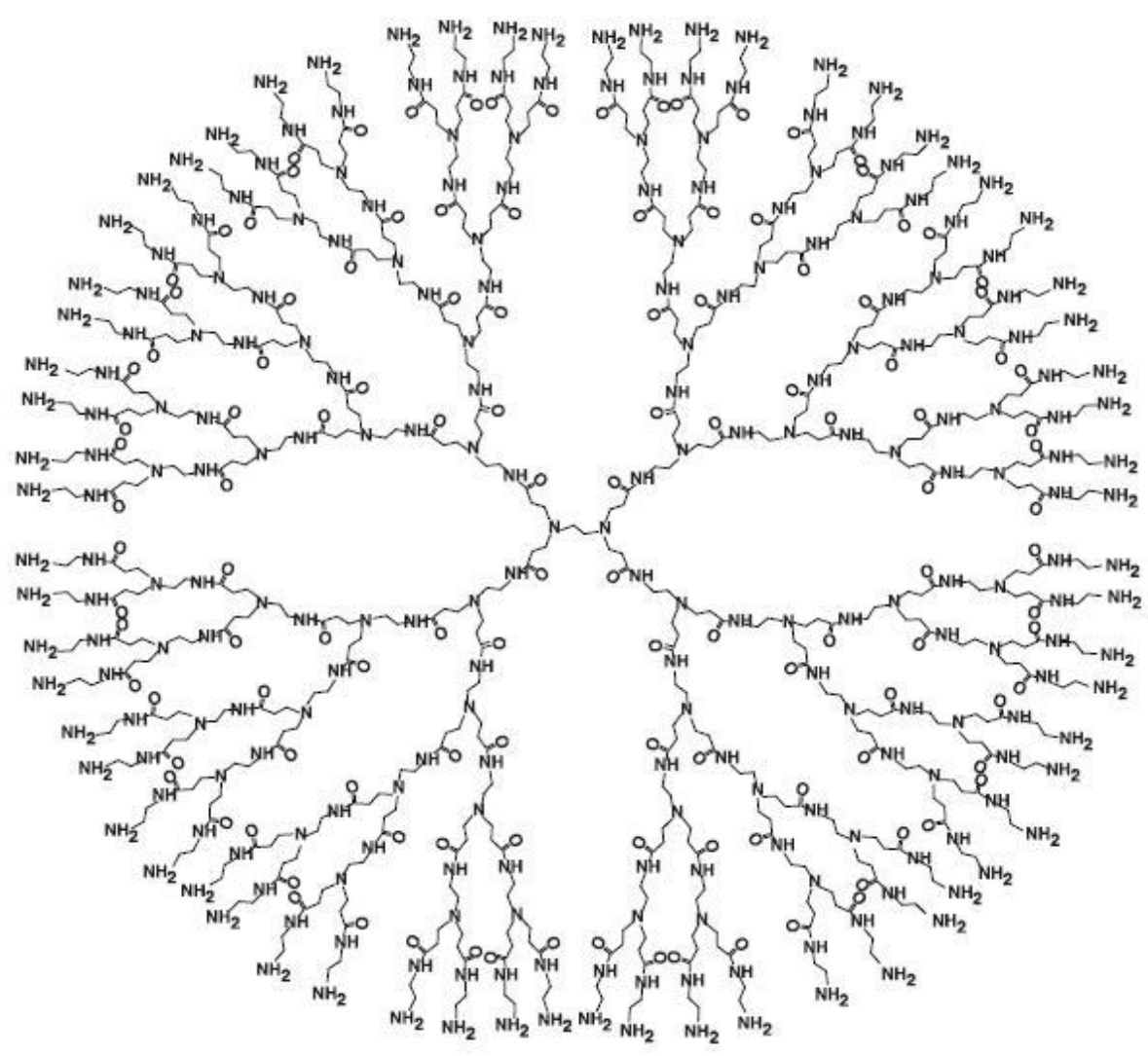


Figure 2

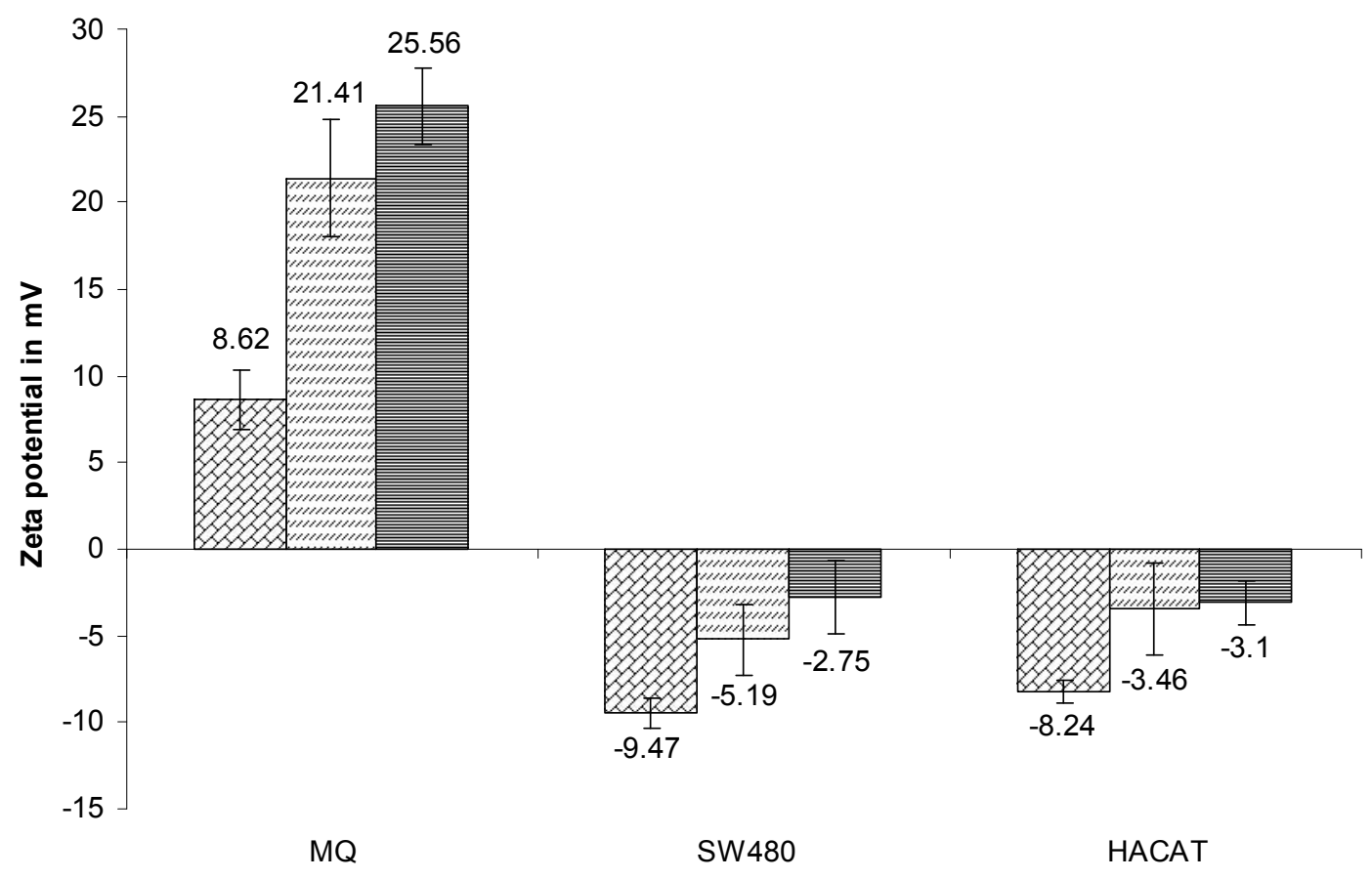


Figure 3
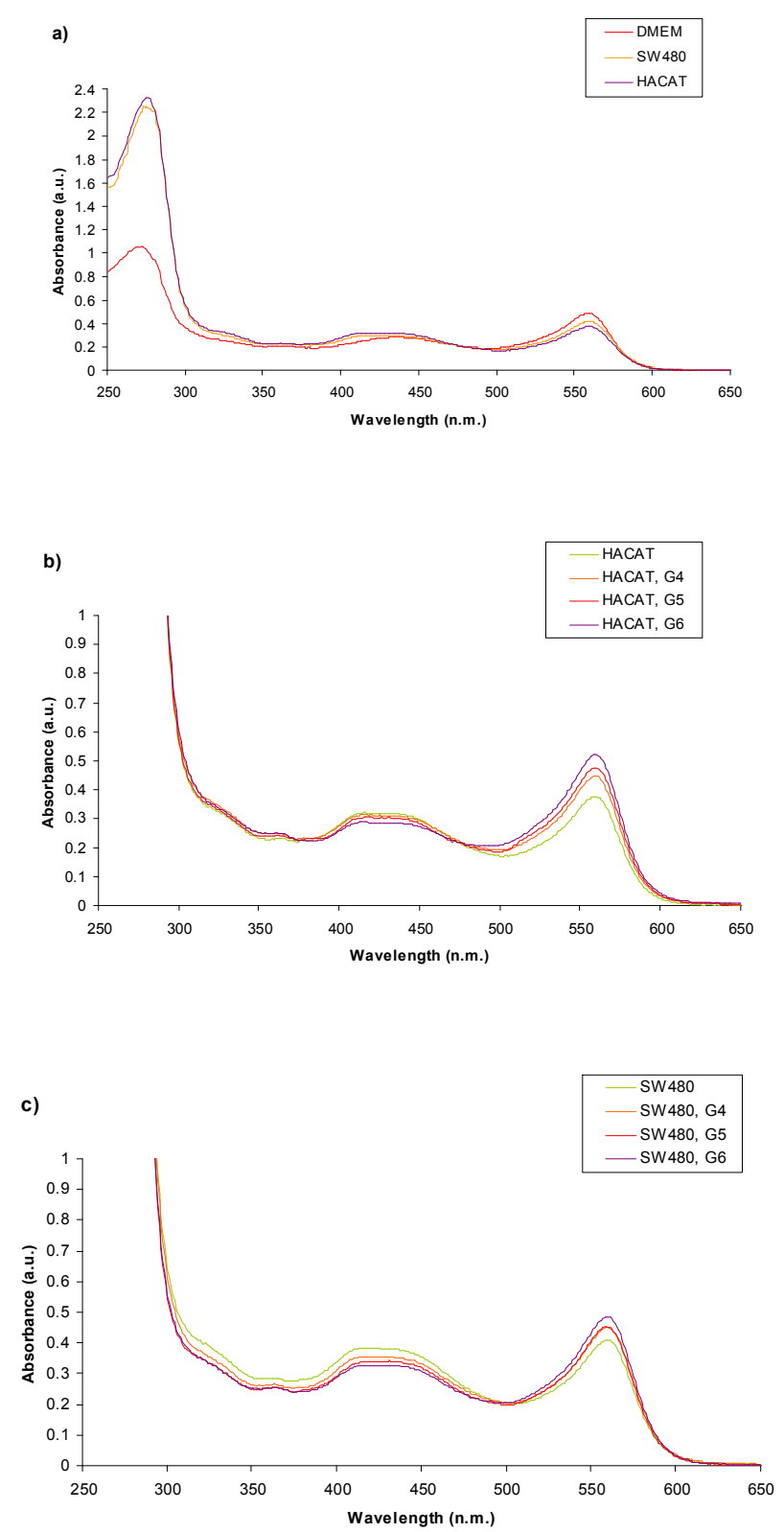
Figure 4

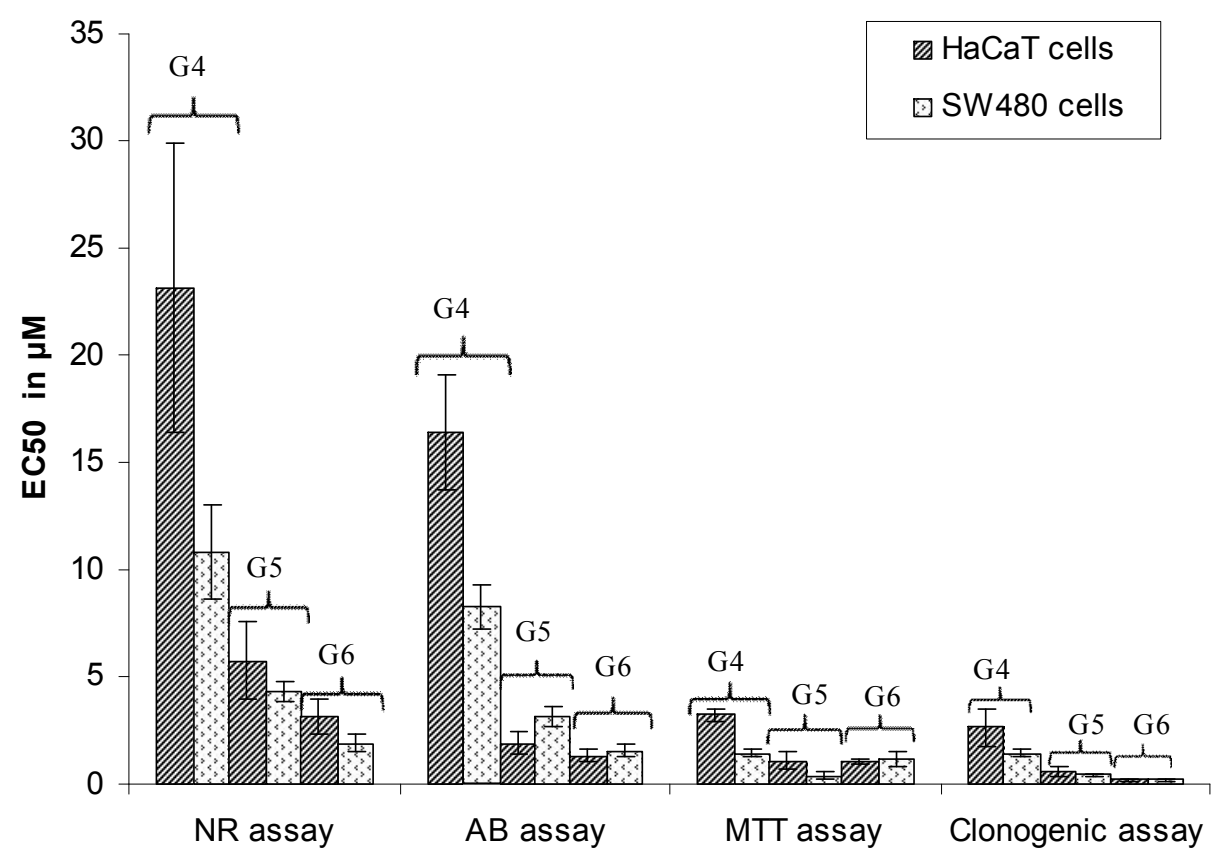


Figure 5

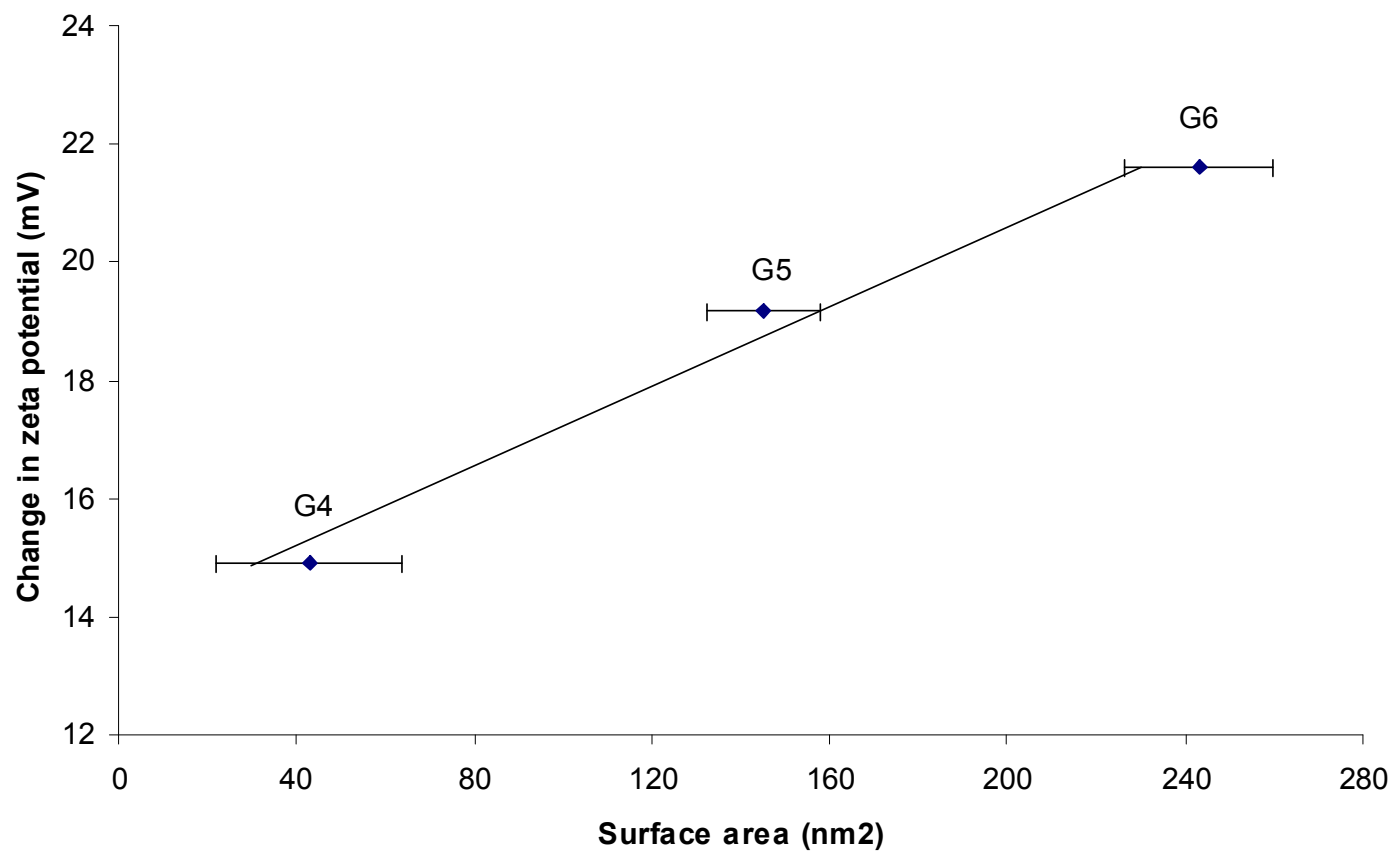


Figure 6

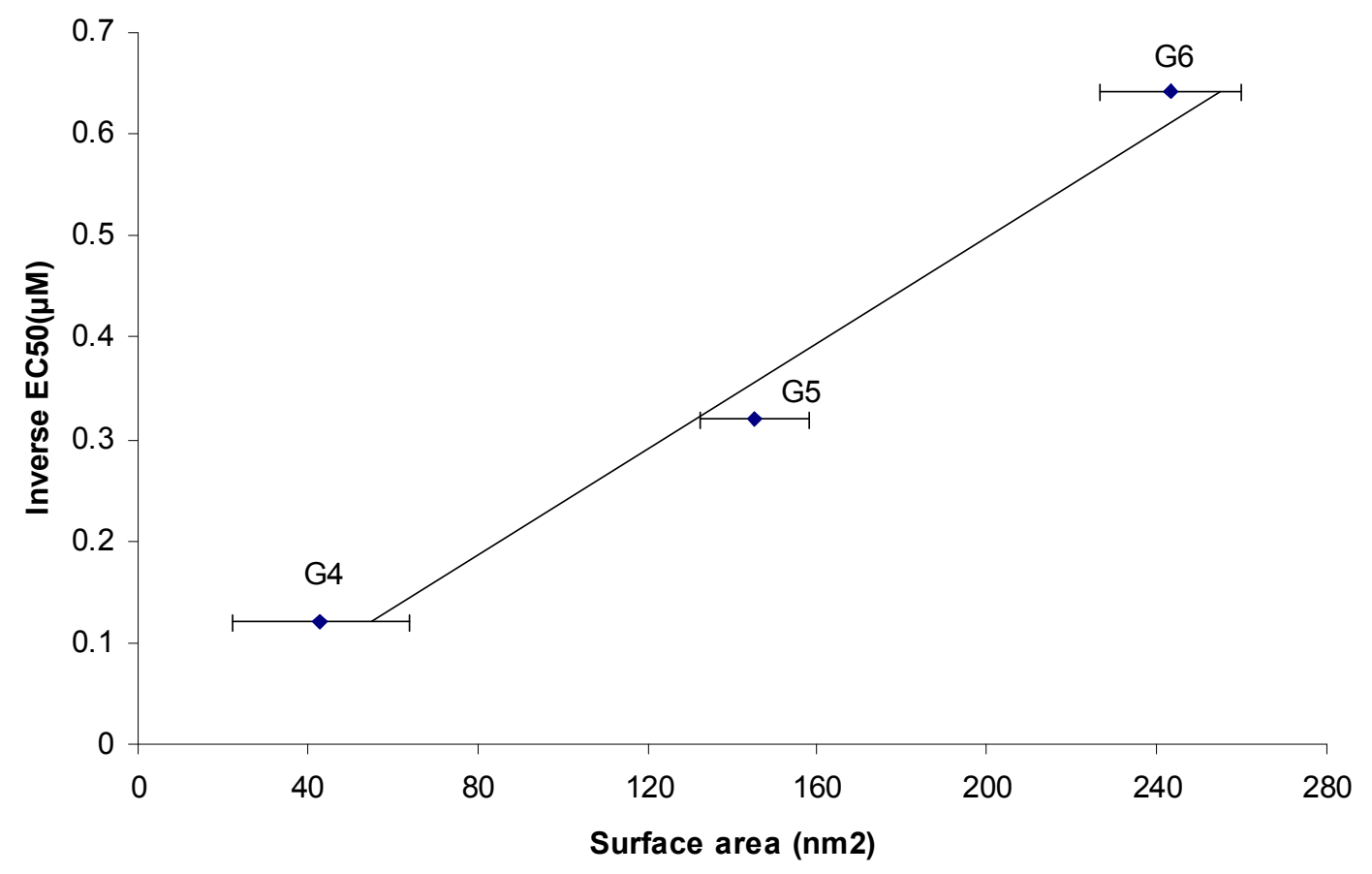


Figure 7

a)

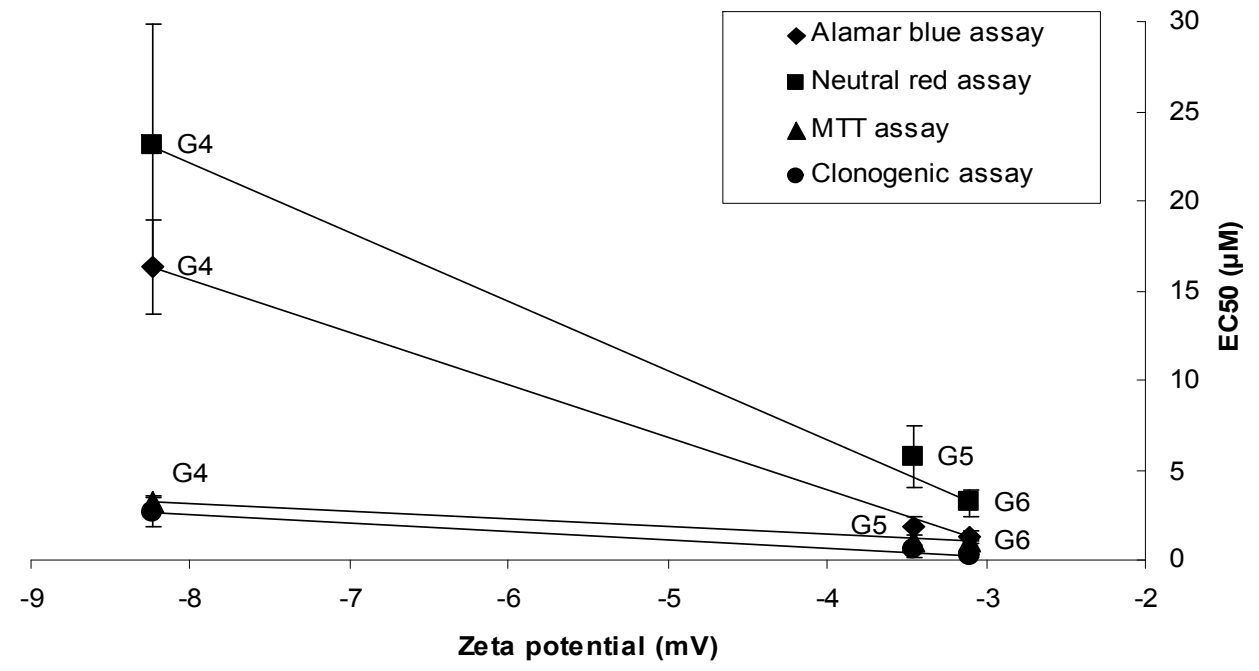

b)

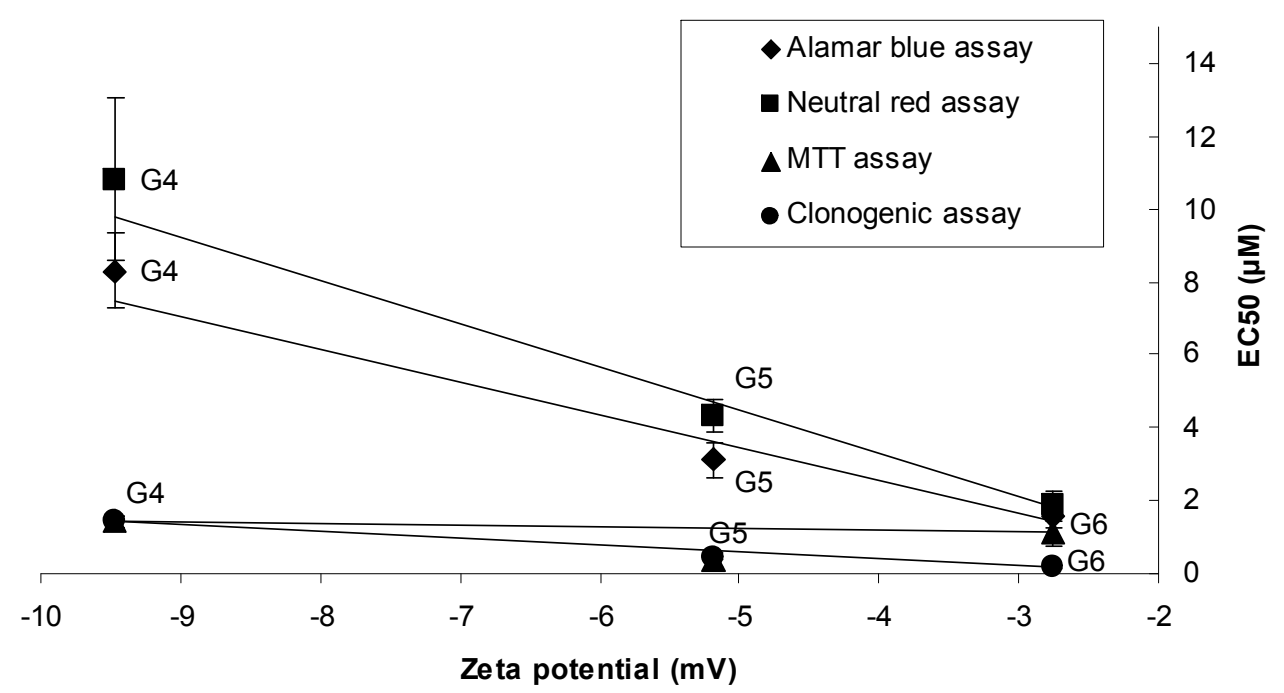


Figure 8

a)

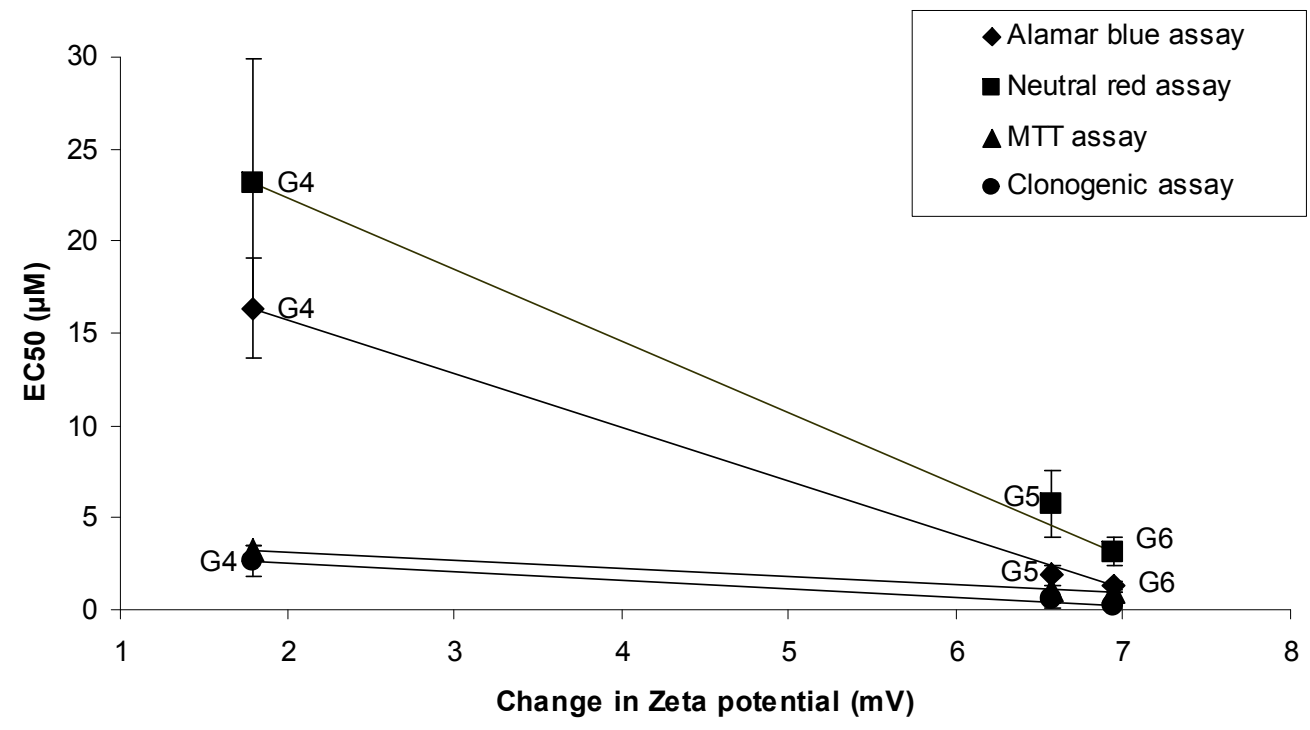

b) 


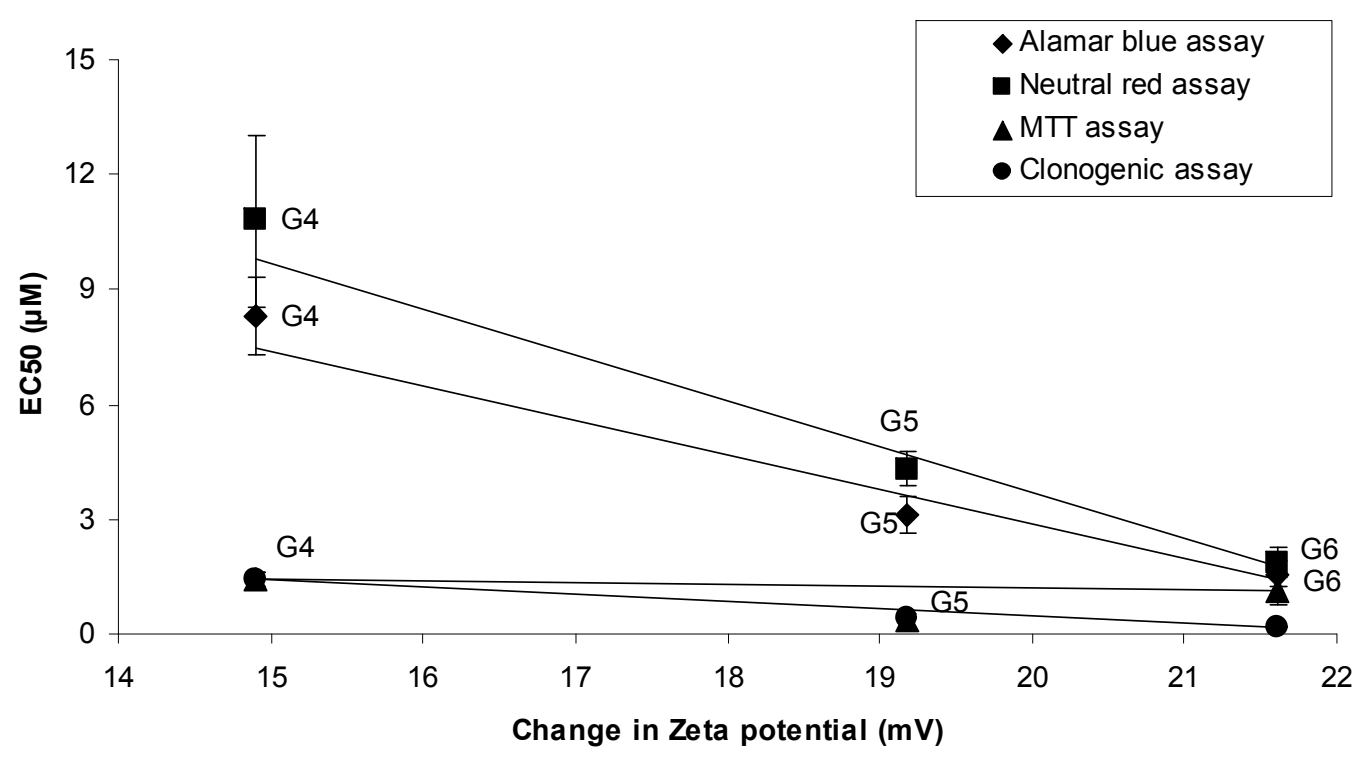

